\title{
Silicon and Aluminum Mobility in Soils of Jeju Island, Korea
}

\author{
Won-Pyo Park $\mathbb{D}^{1}$ and Bon-Jun Koo $\mathbb{D}^{2}$ \\ ${ }^{1}$ Major of Plant Resources and Environment, Jeju National University, Jeju 63243, Republic of Korea \\ ${ }^{2}$ Department of Biological Sciences, California Baptist University, Riverside, CA 92504-3297, USA \\ Correspondence should be addressed to Bon-Jun Koo; bonjunkoo@calbaptist.edu
}

Received 20 March 2020; Revised 21 September 2020; Accepted 26 September 2020; Published 10 October 2020

Academic Editor: Claudio Cocozza

Copyright (c) 2020 Won-Pyo Park and Bon-Jun Koo. This is an open access article distributed under the Creative Commons Attribution License, which permits unrestricted use, distribution, and reproduction in any medium, provided the original work is properly cited.

\begin{abstract}
The objective of the study is to investigate the effect of released silicon ( $\mathrm{Si}$ ) and aluminum (Al) during the formation of volcanic ash soil on the content of Si in groundwater on Jeju Island. Volcanic ash soils in Jeju Island were formed from pyroclastic materials that originated from basalt. We sampled four profiles, including basaltic bedrock of each soil series with large variations in elevation (160-320 m) and mean annual precipitation (MAP; 1,800-2,600 mm). The soil and bedrock minerals were analyzed for weathering of volcanic ash soils related to mineralogical transformations and mobility of Si and Al. Andisols (above 2,000 mm MAP) were dominantly composed of allophane and gibbsite. In Andisols used in the study, 10-70\% of Si was lost, whereas the amount of $\mathrm{Al}$ was relatively conserved. This is because $\mathrm{Al}$ forms Al-humus complex and Andisols contain allophane. In contrast, non-Andisols located at low altitude with lower than 1,800 mm MAP were enriched with considerable amounts of Si and Al, because non-Andisols have crystalline clay minerals and quartz. These results indicate that Andisols, which are widely distributed in Jeju Island, may play an important role in contributing to the high concentration of dissolved Si in the groundwater.
\end{abstract}

\section{Introduction}

On Jeju Island, where no perennial streams or rivers exist, $\mathrm{Si}$ released by weathering and dissolved in the soil solution is likely to be leached into groundwater [1]. The median concentration of Si in Jeju Island groundwater was measured to be $33.6 \mathrm{mg} \mathrm{SiO} 2 \cdot \mathrm{L}^{-1}$ (maximum value: $63 \mathrm{mg} \mathrm{SiO}{ }_{2} \cdot \mathrm{L}^{-1}$ ), which is 1.8 -fold higher than the median concentration of potable spring bottled water produced in Korea $(19.2 \mathrm{mg}$ $\mathrm{SiO}_{2} \cdot \mathrm{L}^{-1}$ ) [2, 3]. Compared with average concentrations, higher Si concentration in water, along with higher $\mathrm{Ca}$ and $\mathrm{K}$ concentration, improves water taste and has greater health benefits [4]. Silicon accounts for more than $80 \%$ of the components that give good taste to Jeju Island's drinking water [2]. Moreover, researchers have reported that $\mathrm{Si}$ contained in drinking water contributes to the prevention of Alzheimer's disease through its antiarteriosclerosis effect, inhibiting the body's absorption of aluminum (Al), improving the bone formation, and reducing the cholesterol levels [5-7]. As the greatest part of the drinking water supply of Jeju Island comes from groundwater [8], it is important to identify the source of $\mathrm{Si}$ introduced into Jeju Island groundwater.

In soils derived from pyroclastic materials, short-rangeorder minerals, including allophane, imogolite, and ferrihydrite, are developed. The common soil type are Andisols, which contain large proportions of Al-humus complexes and are greatly affected by climate in the process of soil formation $[9,10]$. Temperature and precipitation play a crucial role in the weathering of soils derived from pyroclastic materials and in the formation of secondary minerals [9]. According to the previous research on the weathering and mineral formation of volcanic ash soils [11-14], Andisols containing allophane as the main clay mineral are formed at higher altitudes. With increasing altitude, the temperature decreases and the precipitation increases, whereas the amount of evapotranspiration decreases, thus resulting in an increase in the proportions of leached Si and bases. In contrast, non-Andisols with layered silicates as the main clay mineral are formed at lower altitudes, where precipitation decreases and evapotranspiration increases, resulting in the decrease in the proportion of leached Si. 
Leached Si associated with the formation and development of Andisols is presumed to be the major source of Si dissolved into Jeju Island groundwater.

The soils of Jeju Island are volcanic ash soils derived from basalt pyroclastic materials as the main parent material [15], and they have developed into various soil series as a consequence of regional differences in precipitation [1]. According to the Taxonomical Classification of Korean Soils [15], the soils of Jeju Island are classified into 7 orders, 11 suborders, 15 great groups, 28 subgroups, and 66 series. Andisols (38 soil series) account for $80 \%$ of Jeju Island soils concentrated in the center and southeastern regions of the island characterized by heavy precipitation [1]. In the western and northern regions and in the midmountainous area with lower precipitation levels, non-Andisols are widely distributed $[1,16,17]$. Song and Yoo [17] reported that the precipitation levels in the western and northern regions, with mean annual precipitation (MAP) of 1,200-1,800 mm, are high enough to form allophane. However, allophane formation is hampered by high contents of bases, including $\mathrm{Mg}$ and $\mathrm{Na}$, which are characteristics for basalt-derived soils. Strong winds lead to an increased amount of evapotranspiration and, consequently, a small difference between precipitation and evaporation will occur. As a result, soils of Jeju Island can vary considerably in mineral composition and chemical components because $\mathrm{Si}$ and $\mathrm{Al}$ are accumulated or lost, developing into Andisols or non-Andisols, as determined by weathering and climate conditions during pedogenesis.

Previous studies on weathering and pedogenesis of Jeju Island soils described the conditions needed for allophane formation, mineral composition of soils on the island, and chemical components in some of the soil series present on the island [17-21]; however, no research has yet been conducted to investigate the mobility of soil elements during weathering and pedogenic processes. As weathering causes many elements to mobilize and the formation of secondary minerals, changes in element composition as a consequence of mobilization and redistribution within the soil profile can be estimated by calculating mass balance based on element concentrations in bedrock [22-25].

In the present study, we investigated the changes in mineral composition of soil by sampling the soil profiles and basaltic bedrock collected from the lower part of the C-horizon of the soils in the study areas (Andisols in the eastern region and nonAndisols in the northern region). We compared the $\mathrm{Si}$ and $\mathrm{Al}$ mobility patterns in these soils according to the changes in their chemical composition. With regard to Si leaching, we sought to uncover the reason for the high Si concentration in groundwater by investigating the formation and transformation processes of clay minerals, including allophane and Al-humus complexes in volcanic ash soils derived from basaltic pyroclastic materials on Jeju Island.

\section{Materials and Methods}

2.1. Soil Samples. Soil samples for four different soil types were collected in the eastern region (Pyeongdae and Namwon series) and the northern region of Jeju Island (Jeju and Gangjeong series) based on the laboratory characteristics data of the typifying pedon in accordance with the Taxonomical Classification of Korean Soils [15]. All soil samples were derived from basaltic pyroclastic materials [15]. The soils in the eastern region (Pyeongdae and Namwon series, classified as Andisols) are distributed across the lava plateau. The soils in the northern region (Jeju and Gangjeong series, classified as Ultisols and Alfisols, respectively) are distributed across the lava plateau on gentle slopes (Table 1). The northern region where the Jeju series was sampled is situated at a relatively high altitude of $280 \mathrm{~m}$ where the soil progressively develops into Andic Ultisols in the transition zone, indicating a gradual transition to Andisols. The soils from the Jeju and Gangjeong series have an argillic horizon in the form of clay deposits remained after the mobilization of soil water downwards under conditions unsuitable for erosion and sediment deposition $[15,16]$. Soil samples were taken from each soil horizon. Additionally, basaltic bedrock was collected from the lower C-horizon of the soil profile.

2.2. Estimation of Mean Annual Precipitation (MAP) of the Study Area. The mean annual precipitation of Jeju Island widely varies by region. The MAPs (in the period from 1998 to 2010) in the eastern, western, southern, and northern regions were $1,967 \mathrm{~mm}, 1,143 \mathrm{~mm}, 1,923 \mathrm{~mm}$, and $1,498 \mathrm{~mm}$, respectively. There is little regional difference in evapotranspiration, which was measured to be $1,229 \mathrm{~mm}$ and $1,207 \mathrm{~mm}$ in Western Gosan and Southeastern Seoguipo, respectively [26]. Influenced by the topographical characteristics of Mt. Halla, the MAP increased by $100-150 \mathrm{~mm}$ per $100 \mathrm{~m}$ elevation, with the MAP at the summit of Mt. Halla (1950 $\mathrm{m}$ above sea level) exceeding 4,000 mm [1, 8].

The MAPs of the study area were predicted in order to evaluate the mineral composition of the soil samples and the mobility of $\mathrm{Si}$ and $\mathrm{Al}$ according to the precipitation difference. The MAP was determined by substituting the altitude of the sampling points using the data from the equation representing the relationship between MAP and altitude, as analyzed by the Korean Institute of Geoscience and Mineral Resources (KIGAM) [27] (Table 1). KIGAM [27] analyzed the altitude-dependent MAP at four regional stations in Jeju Island from 1992 to 2009 using the linear equation for MAP $(y)$ over the meteorological station altitude $(x)$ : for the northern region $(y=1.5277 x+1432.8$; $\left.R^{2}=0.9197\right)$, western region $\quad(y=1.4422 x+1196$; $\left.R^{2}=0.6163\right), \quad$ southern region $\quad(y=0.6991 x+1907.7$; $\left.R^{2}=0.289\right)$, and eastern region $(y=2.352 x+1905.6$; $\left.R^{2}=0.8404\right)$. The MAPs of the northern, western, southern, and eastern regions increased by 153, 144, 70, and $235 \mathrm{~mm}$, respectively, per $100 \mathrm{~m}$ of elevation.

2.3. Soil Analysis. The collected soils were air-dried and sieved through a $2 \mathrm{~mm}$ sieve for the analysis of key soil properties (Table 2). Unless otherwise specified, the selected soil properties were analyzed according to the Soil Survey Laboratory Methods Manual [28]. Bulk density was 
TABle 1: Site characteristics of the four investigated soil profiles derived from pyroclastic materials in Jeju Island, Korea.

\begin{tabular}{lccccc}
\hline Soil series & $\begin{array}{c}\text { Elevation } \\
(\mathrm{mas})\end{array}$ & $\begin{array}{c}\mathrm{MAP}^{\dagger} \\
\left(\mathrm{mm} \cdot \mathrm{yr}^{-1}\right)\end{array}$ & Vegetation & Coordinates & Soil taxonomy \\
\hline Pyeongdae & 320 & 2,660 & Wild grasses & $\begin{array}{c}\mathrm{N} 33^{\circ} 26^{\prime} 01.5^{\prime \prime} \\
\mathrm{E} 126^{\circ} 43^{\prime} 30.4^{\prime \prime}\end{array}$ & Acrudoxic Melanudands \\
\hline Namwon & 165 & 2,290 & Pasture, wild grass & $\begin{array}{c}\mathrm{N} 33^{\circ} 22^{\prime} 03.5^{\prime \prime} \\
\mathrm{E} 126^{\circ} 45^{\prime} 34.5^{\prime \prime}\end{array}$ & Acrudoxic Melanudands \\
\hline Jeju & 280 & 1,860 & Pinus thunbergii & $\begin{array}{c}\mathrm{N} 33^{\circ} 26^{\prime} 58.5^{\prime \prime} \\
\mathrm{E} 126^{\circ} 31^{\prime} 09.7^{\prime \prime}\end{array}$ & Andic Palehumults \\
\hline Gangjeong & 200 & 1,740 & Pinus thunbergii & $\begin{array}{c}\mathrm{N} 33^{\circ} 27^{\prime} 36.8^{\prime \prime} \\
\mathrm{E} 126^{\circ} 29^{\prime} 07.7^{\prime \prime}\end{array}$ & Mollic Paleudalfs \\
\hline
\end{tabular}

${ }^{\dagger}$ Mean annual precipitation.

TABle 2: Physical and chemical properties of the soils studied in Jeju Island.

\begin{tabular}{|c|c|c|c|c|c|c|c|c|c|c|c|c|}
\hline Horizon & $\begin{array}{l}\text { Depth } \\
(\mathrm{cm})\end{array}$ & $\begin{array}{c}\text { Munsell color } \\
\text { (Moist) }\end{array}$ & $\begin{array}{c}\mathrm{Bd} \\
\left(\mathrm{Mg} \cdot \mathrm{m}^{-3}\right)\end{array}$ & $\begin{array}{c}\mathrm{pH} \\
\left(\mathrm{CaCl}_{2}\right)\end{array}$ & $\begin{array}{c}\mathrm{OC} \\
\left(\mathrm{g} \cdot \mathrm{kg}^{-1}\right)\end{array}$ & $\begin{array}{l}\text { BS } \\
(\%)\end{array}$ & $\begin{array}{l}\mathrm{Si}_{\mathrm{o}} \\
(\%)\end{array}$ & $\begin{array}{l}\mathrm{Al}_{\mathrm{p}} \\
(\%)\end{array}$ & $\begin{array}{l}\text { Alo. } \\
(\%)\end{array}$ & $\begin{array}{l}\text { Ferr. } \\
(\%)\end{array}$ & $\mathrm{Al}_{p} / \mathrm{Al}_{o}$ & MI \\
\hline \multicolumn{13}{|c|}{ Pyeongdae } \\
\hline A & $0-18$ & $10 \mathrm{YR} 2 / 1$ & 0.51 & 4.87 & 120 & 2.74 & 0.77 & 1.88 & 7.27 & 4.10 & 0.44 & 1.49 \\
\hline $\mathrm{AB}$ & $18-44$ & $10 \mathrm{YR} 2 / 2$ & 0.52 & 5.05 & 87.3 & 4.48 & 1.69 & 0.91 & 15.9 & 7.50 & 0.17 & 1.49 \\
\hline Bw1 & $44-73$ & 10 YR 3/4 & 0.60 & 5.24 & 43.7 & 4.89 & 1.75 & 0.41 & 13.3 & 8.12 & 0.11 & 1.47 \\
\hline Bw2 & $73-100$ & $10 \mathrm{YR} 4 / 4$ & 0.71 & 5.36 & 23.0 & 5.68 & 2.13 & 0.21 & 15.2 & 12.07 & 0.05 & 1.38 \\
\hline $\mathrm{BC}$ & $100-140$ & 7.5 YR 4/4 & 0.72 & 5.59 & 15.4 & 5.98 & 3.03 & 0.17 & 19.5 & 12.48 & 0.04 & 1.26 \\
\hline \multicolumn{13}{|l|}{ Namwon } \\
\hline A1 & $0-26$ & $10 \mathrm{YR} 2 / 1$ & 0.57 & 4.36 & 118 & 3.74 & 0.42 & 2.10 & 3.95 & 5.15 & 0.59 & 1.52 \\
\hline A2 & $26-47$ & $10 \mathrm{YR} 2 / 2$ & 0.57 & 4.61 & 104 & 2.90 & 0.47 & 2.38 & 4.43 & 5.68 & 0.60 & 1.51 \\
\hline $\mathrm{AB}$ & $47-72$ & $10 \mathrm{YR} 3 / 2$ & 0.59 & 4.69 & 91.5 & 3.48 & 0.69 & 2.28 & 6.52 & 6.30 & 0.52 & 1.52 \\
\hline $\mathrm{Bw}$ & $72-160$ & $10 \mathrm{YR} 4 / 4$ & 0.74 & 4.94 & 30.6 & 7.95 & 1.06 & 0.50 & 9.95 & 9.07 & 0.16 & 1.43 \\
\hline \multicolumn{13}{|l|}{ Jeju } \\
\hline Ap & $0-20$ & $10 \mathrm{YR} 3 / 2$ & 0.92 & 4.41 & 37.8 & 2.08 & 0.17 & 0.90 & - & 3.24 & 0.59 & - \\
\hline $\mathrm{AB}$ & $20-41$ & $10 \mathrm{YR} 3 / 3$ & 1.03 & 4.36 & 19.9 & 1.73 & 0.19 & 0.69 & - & 2.94 & 0.55 & - \\
\hline Bt1 & $41-65$ & $10 \mathrm{YR} 4 / 3$ & 1.29 & 4.29 & 9.80 & 3.81 & 0.14 & 0.47 & - & 2.37 & 0.63 & - \\
\hline Bt2 & $65-92$ & 7.5 YR 4/4 & 1.48 & 4.19 & 7.12 & 6.32 & 0.13 & 0.36 & - & 2.08 & 0.56 & - \\
\hline Bt3 & $92-150$ & 7.5 YR 4/4 & 1.48 & 4.12 & 6.40 & 10.1 & 0.16 & 0.28 & - & 2.06 & 0.46 & - \\
\hline \multicolumn{13}{|c|}{ Gangjeong } \\
\hline Ap & $0-24$ & 10 YR $3 / 3$ & 1.05 & 4.79 & 30.2 & 53.3 & 0.20 & 0.36 & - & 2.34 & 0.52 & - \\
\hline Bat & $24-38$ & $10 \mathrm{YR} 4 / 3$ & 1.36 & 4.52 & 13.9 & 43.5 & 0.09 & 0.24 & - & 1.06 & 0.57 & - \\
\hline Bt1 & $38-53$ & $10 \mathrm{YR} 4 / 4$ & 1.48 & 4.53 & 5.15 & 45.0 & 0.09 & 0.13 & - & 0.94 & 0.41 & - \\
\hline $\mathrm{Bt} 2$ & $53-85$ & 10 YR $4 / 4$ & 1.53 & 4.47 & 2.86 & 50.5 & 0.11 & 0.09 & - & 1.31 & 0.31 & - \\
\hline $\mathrm{Bt} 3$ & 85-135 & $10 \mathrm{YR} 4 / 6$ & 1.53 & 4.42 & 1.92 & 57.0 & 0.13 & 0.08 & - & 2.00 & 0.27 & - \\
\hline
\end{tabular}

Bd: bulk density, OC: organic carbon, BS: base saturation, Sio: acid oxalate extractable Si, Alp: sodium pyrophosphate extractable Al, Alo: allophane, Ferr: ferrihydrite, MI: melanic index.

calculated using a $100 \mathrm{~cm}^{3}$ core sample dried at $105^{\circ} \mathrm{C}$. Soil $\mathrm{pH}$ was measured with a $\mathrm{pH}$ meter (Orion Star A211, Thermo Scientific, USA) after mixing the soil with $0.01 \mathrm{M}$ $\mathrm{CaCl}_{2}$ in a ratio of $1: 2$ and shaking the mixture. Soil organic carbon was determined by the Walkley-Black wet digestion method. Base saturation was computed by analyzing the exchangeable cations and cation exchange capacity after leaching extraction of cations in $1 \mathrm{M} \mathrm{NH}_{4} \mathrm{OAc}$ solution ( $\mathrm{pH}$ 7.0). Organically bound $\mathrm{Al}\left(\mathrm{Al}_{p}\right)$ was extracted for $16 \mathrm{~h}$ with $0.1 \mathrm{M}$ sodium pyrophosphate at $\mathrm{pH} 10$. The extraction of $\mathrm{Al}$, $\mathrm{Fe}$, and $\mathrm{Si}$ associated with organically complexed $\mathrm{Fe}$ and $\mathrm{Al}$, noncrystalline hydrous oxides of $\mathrm{Fe}$ and $\mathrm{Al}$, allophane, and amorphous aluminosilicates $\left(\mathrm{Al}_{o}, \mathrm{Fe}_{o}\right.$, and $\left.\mathrm{Si}_{o}\right)$ was carried outusing a mechanical vacuum extractor with $0.2 \mathrm{M}$ ammonium oxalate adjusted to $\mathrm{pH} 3.0$ with oxalic acid for $12 \mathrm{~h}$ in the dark. The extraction solution was centrifuged, and the filtrate was diluted with distilled water and measured with ICP-OES (JY 138 Ultrace, Jobin Yvon, France). Allophane and ferrihydrite contents were calculated using the formulas $100 \times \mathrm{Si}_{o} /\left\{-5.1\left[\left(\mathrm{Al}_{o}-\mathrm{Al}_{p}\right) / \mathrm{Si}_{\mathrm{o}}\right.\right.$ atomic ratio $\left.]+23.4\right\}$ [29] and $\mathrm{Fe}_{o} \times 1.7$ [30], respectively. Melanic index (MI) was calculated with the absorbance ratio of $450 / 520 \mathrm{~nm}$ by measuring the absorbance of the filtrate with UV/Vis spectrometer (Lambda 25, PerkinElmer, USA) at wavelengths of $450 \mathrm{~nm}$ and $520 \mathrm{~nm}$ after shaking it for $1 \mathrm{~h}$ in a solution of $0.1 \%$ $\mathrm{NaOH}$. If the MI was 1.7 or less in Andisols, it was determined that the soil contained melanic epipedons [31].

2.4. XRD and SEM/EDS Analyses. To determine the mineral compositions of the soil samples from the two different regions, we performed X-ray diffraction (XRD) and scanning electron microscope/energy-dispersive 
X-ray spectroscopy (SEM/EDS) analysis. To prepare bulk specimens for XRD analysis, we subjected the typifying pedon and rock powder sample of each layer to uniform crushing, sieving with a $0.015 \mathrm{~mm}$ sieve, and oven-drying at $105^{\circ} \mathrm{C}$ for $24 \mathrm{~h}$. XRD analysis was performed with an $\mathrm{X}$-ray powder diffractometer (Geigerflex 2013, Rigaku, Japan) that uses $\mathrm{CuK} \alpha$ rays and $\mathrm{Ni}$-filtered $\mathrm{X}$-rays and operates at $30 \mathrm{kV}$ and $15 \mathrm{~mA}$, at a scan speed of $2^{\circ} 2 \theta / \mathrm{min}$, repetition time of $1 \mathrm{~s}$, and a slit of $1^{\circ}-0.3 \mathrm{~mm}-1^{\circ}$. For accurate analysis of clay mineral types, the selected subsoil horizon within each soil profile was dispersed in distilled water and the dispersed solution was centrifuged at 5,000 rpm, after which the clay-sized fractions finer than $2 \mu \mathrm{m}$ were separated. The separated clay samples were air-dried, heat-treated at $550^{\circ} \mathrm{C}$ or treated with ethylene glycol (EG), and subjected to XRD analysis. Semiquantitative analysis was performed using a quantitative analysis program (SIEROQUANT ${ }^{\mathrm{TM}}$, version 3.0). To observe the morphological properties of the clay minerals in the soil samples, SEM/EDS analysis was performed at an acceleration voltage of $15 \mathrm{kV}$ using FESEM SUPRA25 (Zeiss, Germany) and ELPHY Quantum (Raith, Germany).

2.5. Mobilities of Si and Al. To compare the changes in Si and $\mathrm{Al}$ contents in the soils formed in two different regions, we prepared fine powders from bulk soil samples and basaltic bedrock collected from the lower part of the C-horizon of each soil profile. The samples were digested in a microwave oven using $\mathrm{HNO}_{3}, \mathrm{HCl}, \mathrm{HF}$, and $\mathrm{H}_{3} \mathrm{BO}_{3}$ solutions [28], and the compounds containing $\mathrm{Si}$ and $\mathrm{Al}$ were measured with ICP-OES (JY 138 Ultrace, Jobin Yvon, France) and those containing $\mathrm{Zr}$ and $\mathrm{Nb}$ with ICP-MS (Varian 820-MS, Australia) (Table S1).

In the process of chemical weathering, mass balance calculation in a soil profile was used to estimate the mobility of elements by comparing the concentrations of these elements in bedrock [22-25]. In each soil profile, element losses/gains relative to that in the bedrock were calculated using the following equation:

$$
\tau_{i, j}=\left(\frac{C_{j, w}}{C_{j, p}} \times \frac{C_{i, p}}{C_{i, w}}\right)-1,
$$

where $C_{j, w}$ and $C_{j, p}$ are the concentrations of an element $(j)$ in the weathered soil $(w)$ and bedrock $(p)$, and $C_{i, w}$ and $C_{i, p}$ are the concentrations of an immobile element $(i)$ in the weathered soil $(w)$ and bedrock $(p), \tau=0$ indicates no element change compared with the initial bedrock composition, $\tau>0$ indicates enrichment of an element, and $\tau<0$ indicates a loss of an element.

A reference element was selected based on the bedrock type and climate with the consideration that the amount of element mass transfer can be overestimated or underestimated depending on the selected reference element $[32,33]$. Given that the amount of element mass transfer in volcanic ash soils relative to bedrock is usually estimated using $\mathrm{Ti}, \mathrm{Zr}$, or $\mathrm{Nb}$ as the immobile element, [14, 22-25], we considered the possibility of using $\mathrm{Zr}, \mathrm{Nb}$, or $\mathrm{Ti}$ as the immobile element as per equation (1). When $\mathrm{Zr}$ was selected as the reference element in the Namwon, Jeju, and Gangjeong series, $\mathrm{Nb}$ underwent a loss of 3-20\%, and selecting $\mathrm{Nb}$ as the reference element resulted in the enrichment of $\mathrm{Zr}$. In the Pyeongdae series, when $\mathrm{Nb}$ was selected as the reference element, $\mathrm{Zr}$ underwent a loss of 2-8\%, showing the opposite tendency to that in the Namwon, Jeju, and Gangjeong series (Figure 1). In all sampled soils, selecting $\mathrm{Ti}$ as the reference element led to the enrichment of $\mathrm{Zr}$ and $\mathrm{Nb}$ by $10-80 \%$ (data not shown). This can be ascribed to the loss of $\mathrm{Ti}$ in the weathering process [22]. In all soil series except for the Namwon series, $\mathrm{Zr}$ and $\mathrm{Nb}$ were reprecipitated and no mobilization took place in the subsoil horizon. However, when $\mathrm{Zr}$ was selected as the reference element in the Namwon series, $20 \%$ of $\mathrm{Nb}$ was lost in the subsoil horizon relative to that in the bedrock. In the Pyeongdae series, when $\mathrm{Zr}$ and $\mathrm{Nb}$ were selected as reference elements, both elements were lost or enriched to a small extent. Therefore, in the present study, we selected $\mathrm{Zr}$ as the best reference immobile element for mass balance calculation.

\section{Results and Discussion}

3.1. Mineral Compositions of Basaltic Bedrock and the Investigated Soils. The main constituent minerals of basaltic bedrock collected from the lower part of the C-horizon of the eastern and northern soil series were plagioclase and pyroxene minerals, with a small amount of K-feldspar, mica, olivine, and magnetite (Table 3). Semiquantitative XRD analysis revealed that plagioclase accounted for $20-70 \%$ of the overall bedrock, and the lowest proportion of plagioclase was observed in the Gangjeong series. The highest proportion of olivine in bedrock was $20 \%$ in the bedrock of the Gangjeong series. K-feldspar, micas, and pyroxene accounted for $12 \%$ of the bedrock in the Jeju series. A small amount of chlorite $(<3 \%)$ was present in the bedrocks of the Pyeongdae, Namwon, and Gangjeong series. Hematite was present only in the bedrocks of the Namwon and Jeju series in small proportions $(<3 \%)$, and magnetite was present in the overall bedrock in the range of $2.5-8.5 \%$. The mineral composition of the bedrocks collected from the investigated soils was similar to that of the Jeju Island basalt analyzed in the previous studies [21, 34].

Regarding the mineral compositions of the sampled soils, all soil samples consisted of both primary and secondary minerals weathered from bedrocks (Table 4). Plagioclase, which accounted for a great proportion of the overall bedrock, was $5.2-17.5 \%$ in the overall soil profile, while K-feldspar and pyroxene were $1.6-11.5 \%$ and $3-10.7 \%$, respectively. Olivine was present in the range of $1-10 \%$ in the Pyeongdae and Namwon series but was not detected in the Jeju and Gangjeong series due to advanced weathering. Iron oxide minerals, including hematite, goethite, and magnetite, were detected, but the Gangjeong series contained hardly any magnetite as a result of oxidation. In contrast, in the Pyeongdae series, a significant amount of residual magnetite was detected, as it was presumably less exposed to oxidation than other soils were. Quartz and gibbsite, which were not present in bedrocks, were detected 


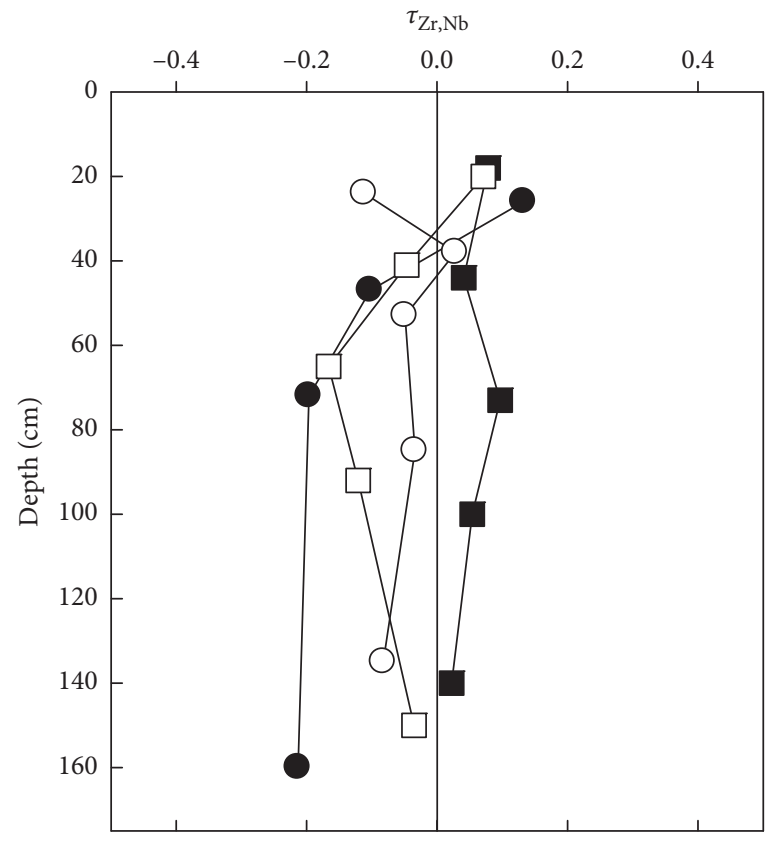

(a)

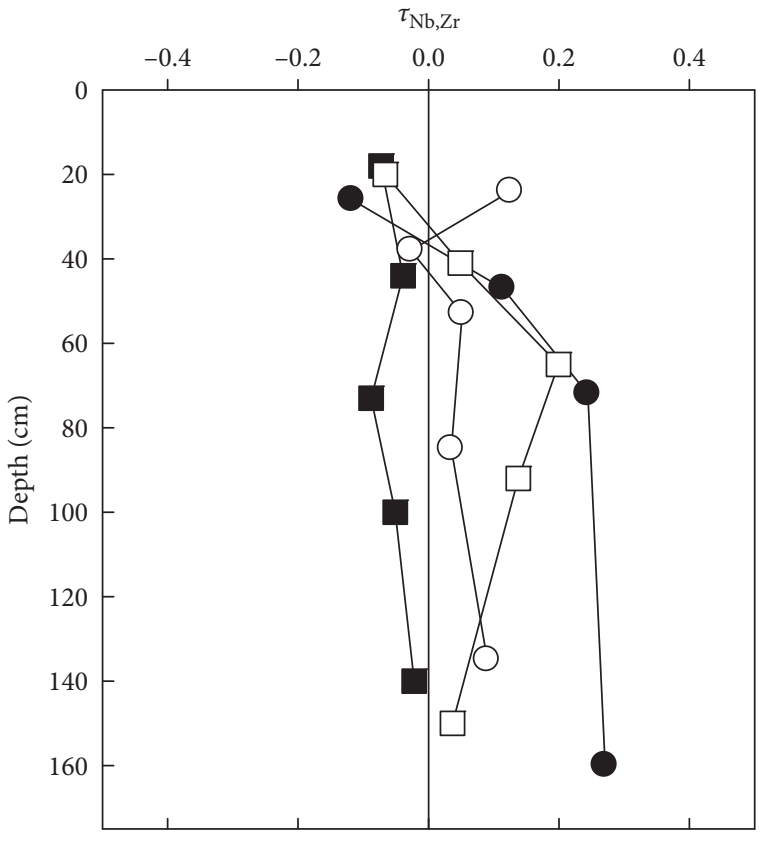

(b)

Figure 1: The variation of mass transfer coefficients for $\mathrm{Nb}$ and $\mathrm{Zr}$ element from four soil profiles ( $\mathbf{\square}$, Pyeongdae; $\bullet$, Namwon; $\square$, Jeju; $\bigcirc$, Gangjeong) using $\mathrm{Zr}$ and $\mathrm{Nb}$ as immobile elements.

TABLe 3: Mineral compositions of basaltic bedrocks.

\begin{tabular}{|c|c|c|c|c|c|c|c|c|}
\hline Soil series & $\begin{array}{l}\text { Plagioclase } \\
\text { (wt. \%) }\end{array}$ & K-feldspars & Micas & Pyroxene & Olivine & Chlorite & Hematite & Magnetite \\
\hline Pyeongdae & 40.7 & 9.1 & 6.4 & 27.3 & 11.3 & 1.4 & - & 3.8 \\
\hline Namwon & 43.7 & 7.6 & 2.7 & 27.5 & 5.0 & 2.1 & 2.8 & 8.5 \\
\hline Jeju & 69.8 & 12.3 & 12.3 & 12.5 & 2.1 & - & 2.7 & 2.6 \\
\hline Gangjeong & 28.4 & 10.5 & 3.2 & 26.3 & 20.4 & 3.1 & - & 8.0 \\
\hline
\end{tabular}

in all soil samples. The quartz content of the Jeju and Gangjeong series (45-55\%) was 2-fold greater than that of the Pyeongdae and Namwon series. The gibbsite contents of the Pyeongdae and Namwon series were $17 \%$ and $10 \%$ in the subsoil horizons, respectively.

Figure 2 shows the results of the XRD analysis of the clay fraction $(<2 \mu \mathrm{m})$ of the horizon selected from each soil profile. Diffracted X-rays of the clay fractions from the Pyeongdae and Namwon series were extremely weak (Figure 2(a)), indicating that these series contained significant amounts of amorphous minerals, such as allophane and ferrihydrite. In contrast, the Jeju and Gangjeong series showed very clear diffracted X-rays with slightly higher concentrations of crystalline secondary minerals than those of the other series (Figure 2(b)). In the XRD patterns of clay fractions, the clay minerals with $14 \AA$-peak areas were confirmed after air drying, ethylene glycerol treatment, and $550^{\circ} \mathrm{C}$ heat treatment. Chlorite was detected in the samples from the Namwon series, and chlorite and a small amount of smectite were detected in the Pyeongdae series. The Jeju and Gangjeong series contained large amounts of chlorite and vermiculite. Except for the bedrock of the Jeju series, small amounts of chlorite were detected in the bedrocks of all other soil series. However, in all of the other soil horizons, significant amounts of chlorite were detected. Transformation of alkaline minerals seems to be responsible for the presence of chlorite in the soil samples, with a large amount of chlorite observed in the soils derived from pyroclastic materials in advanced stages of weathering unlike that in the soils at other stages [18-20,35]. Ha et al. [20] reported that vermiculite evolved into chlorite via the stage of hydroxy-Al interlayered vermiculite in the Dangsanbong soil, i.e., nonAndisols of the western coastal region of Jeju Island. Minerals of the mica group appeared in the peak area of illite (10 $\AA$ ), with illite accounting for $5-12 \%$ of the overall soil. Kaolinite appeared in the $7.1 \AA$ peak area, with its highest fraction $(\sim 4 \%)$ recorded in the Gangjeong series.

3.2. Clay Minerals and Allophane in the Investigated Soils. Figure 3 shows the results of the SEM/EDS analysis of the clay fractions based on the results of the XRD analysis. The Bw2 horizon of the Pyeongdae series was found to contain flaky materials separated from the surface of feldspars, which 
TABLE 4: Mineral compositions of soil samples.

\begin{tabular}{|c|c|c|c|c|c|c|c|c|c|c|c|c|c|c|}
\hline Horizon & $\begin{array}{l}\text { Depth } \\
(\mathrm{cm})\end{array}$ & $\begin{array}{c}\text { Q } \\
\text { (wt. \%) }\end{array}$ & $\mathrm{Pl}$ & K-F & $\mathrm{Mi} / \mathrm{Ill}$ & $\mathrm{Px}$ & $\mathrm{Ov}$ & $\mathrm{K}$ & $\mathrm{Ch}$ & $\mathrm{Ch} / \mathrm{Sm}$ & $\mathrm{Ch} / \mathrm{Vc}$ & $\mathrm{Gb}$ & $\mathrm{Hm} / \mathrm{Gt}$ & $\mathrm{Mg}$ \\
\hline \multicolumn{15}{|c|}{ Pyeongdae } \\
\hline A & $0-18$ & 29.3 & 12.4 & 9.0 & 9.4 & 5.0 & 8.0 & 4.0 & - & 6.7 & - & 3.2 & 7.1 & 5.9 \\
\hline $\mathrm{AB}$ & $18-44$ & 23.2 & 17.5 & 7.8 & 7.2 & 6.8 & 10.0 & 1.2 & - & 8.4 & - & 3.5 & 3.9 & 6.6 \\
\hline Bw1 & $44-73$ & 19.4 & 11.8 & 7.9 & 9.7 & 8.5 & 4.1 & 3.7 & - & 6.3 & - & 17.4 & 5.4 & 5.9 \\
\hline Bw2 & $73-100$ & 20.6 & 11.1 & 6.8 & 8.8 & 8.2 & 4.2 & 3.9 & - & 6.4 & - & 18.6 & 5.3 & 6.1 \\
\hline $\mathrm{BC}$ & $100-140$ & 22.8 & 11.5 & 6.0 & 12.0 & 6.2 & 5.5 & 1.4 & - & 6.4 & - & 17.1 & 3.2 & 7.8 \\
\hline \multicolumn{15}{|l|}{ Namwon } \\
\hline A & $0-26$ & 38.5 & 14.8 & 3.5 & 12.9 & 6.0 & 1.0 & 3.7 & 7.0 & - & - & 3.7 & 5.4 & 3.2 \\
\hline A2 & $26-47$ & 32.8 & 14.8 & 6.5 & 11.4 & 4.4 & 8.0 & 1.8 & 7.6 & - & - & 4.7 & 3.4 & 4.4 \\
\hline $\mathrm{AB}$ & $47-72$ & 39.2 & 11.9 & 7.0 & 12.9 & 2.9 & 1.0 & 2.9 & 8.7 & - & - & 5.9 & 2.3 & 2.7 \\
\hline $\mathrm{Bw}$ & $72-160$ & 33.4 & 16.2 & 5.7 & 9.1 & 5.6 & 2.9 & 2.1 & 9.4 & - & - & 11.2 & 2.8 & 1.7 \\
\hline \multicolumn{15}{|l|}{ Jeju } \\
\hline Ap & $0-20$ & 54.7 & 8.8 & 1.6 & 8.6 & 10.7 & - & 1.7 & - & - & 6.3 & 1.3 & 4.1 & 2.3 \\
\hline $\mathrm{AB}$ & $20-41$ & 49.1 & 9.0 & 11.5 & 5.1 & 7.5 & - & 2.5 & - & - & 9.3 & 1.5 & 2.2 & 2.3 \\
\hline Bt1 & $41-65$ & 51.2 & 7.9 & 4.9 & 7.5 & 6.8 & - & 2.6 & - & - & 12.3 & 2.2 & 3.3 & 1.4 \\
\hline $\mathrm{Bt} 2$ & 65-92 & 48.4 & 5.2 & 2.4 & 10.3 & 9.7 & - & 3.9 & - & - & 11.6 & 3.1 & 3.5 & 2.1 \\
\hline $\mathrm{Bt} 3$ & $92-150$ & 48.3 & 5.4 & 7.0 & 11.1 & 5.2 & - & 3.8 & - & - & 12.8 & 3.2 & 2.4 & 1.0 \\
\hline \multicolumn{15}{|c|}{ Gangjeong } \\
\hline Ap & $0-24$ & 53.6 & 10.5 & - & 11.6 & 7.2 & - & 4.0 & - & - & 6.3 & 2.6 & 3.4 & 0.9 \\
\hline BAt & $24-38$ & 45.5 & 16.6 & 7.0 & 7.4 & 8.9 & 0.4 & 3.1 & - & - & 8.2 & 1.9 & 1.0 & - \\
\hline $\mathrm{Bt} 1$ & $38-53$ & 45.8 & 15.6 & 4.5 & 8.8 & 7.3 & 1.5 & 3.1 & - & - & 8.1 & 1.8 & 3.5 & - \\
\hline $\mathrm{Bt} 2$ & $53-85$ & 51.7 & 10.8 & 4.5 & 9.3 & 5.5 & - & 4.7 & - & - & 9.9 & 1.0 & 2.5 & - \\
\hline Bt3 & $85-135$ & 45.6 & 15.1 & 7.7 & 10.8 & 6.0 & - & 3.5 & - & - & 6.6 & 1.4 & 3.1 & - \\
\hline
\end{tabular}

Q: quartz; Pl: plagioclase; K-F: K-feldspars; Mi/Ill: mica/illite; Hb: hornblende; Px: pyroxene; Ov: olivine; K: kaolinite; Ch/Sm: chlorite/smectite; Gb: gibbsite; $\mathrm{Hm}$ : hematite; Gt: goethite; Mg: magnetite.

were analyzed via EDS and was composed of Si-Al-O (Figure 3(a)), thus matching the kaolinite and allophane ratio of $1: 1$. However, as revealed by XRD analysis, a large amount of amorphous minerals was observed, such that most of the SEM-observed materials could be considered allophanes. The clay minerals observed in the Bt 2 horizon of the Jeju series appeared in the shape of a lump of feldspar crystals of illite as feldspars weathered into platy illite (K$\mathrm{Mg}-\mathrm{Fe}-\mathrm{Al}-\mathrm{Si}-\mathrm{O}$ ) (Figure 3(b)). Chlorite (Mg-Fe-Al-Si-O) appeared in the form of separated platy and flaky crystals (Figure 3(c)). The Btw horizon of the Gangjeong series also consisted predominantly of illite and chlorite, with smaller fractions of kaolinite and vermiculite (Figures 3(d) and 3(e)).

The analysis using the selective dissolution method showed that the allophane content was highest in the overall soil profile of the Pyeongdae series (ranging from 7 to $20 \%$ ), and the median allophane content in the $\mathrm{AB}$ and $\mathrm{Bw}$ horizons of the Namwon series (6.5\% and $10 \%$, respectively) were significantly lower than those in the Pyeongdae series (Table 2). The difference in allophane content between the Pyeongdae and Namwon series can be ascribed to the different ratios of active $\mathrm{Al}$, either as $\mathrm{Al}$-humus complexes $\left(\mathrm{Al}_{p} /\right.$ $\left.\mathrm{Al}_{o}>5\right)$ or as allophane $\left(\mathrm{Al}_{p} / \mathrm{Al}_{o}<5\right)[9,29]$. The presence of allophane is not found when the content of $\mathrm{Si}_{\mathrm{o}}$ extracted with ammonium oxalate is $6 \mathrm{~g} \cdot \mathrm{kg}^{-1}$ or less $[36,37]$. Under the soil conditions of low $\mathrm{pH}$ and high organic carbon content, active $\mathrm{Al}$ favors the formation of $\mathrm{Al}$-humus complexes or forms part of $2: 1$ silicate clay minerals, thus suppressing the formation of allophane $[9,17]$. A1 and A2 horizons of the Namwon series had the $\mathrm{Al}_{p} / \mathrm{Al}_{o}$ ratio of 0.6 , with $\mathrm{Si}_{o}$ contents of $0.42 \%$ and $0.47 \%$, respectively, meaning that in these horizons $\mathrm{Al}$ existed in the form of Al-humus complexes rather than in the form of allophane. However, in the $A B$ horizon of the Namwon series and the A horizon of the Pyeongdae series, the $\mathrm{Al}_{p} / \mathrm{Al}_{o}$ ratios were 0.52 and 0.44 , respectively, with a $\mathrm{Si}_{o}$ content of $0.7 \%$ (Table 2) and $\mathrm{Al}$ humus complexes and allophane coexisting intermingled in equal parts [17]. In the subsoil horizon of both soils, the $\mathrm{Al}_{p} /$ $\mathrm{Al}_{o}$ ratio was below 0.1 , with most of the active $\mathrm{Al}$ existing in the form of allophane.

In the Jeju and Gangjeong series from the northern region, the $\mathrm{Si}_{o}$ content was lower than $0.1 \%$ (Table 2) and the presence of allophane was not recognized. This suggested that the low precipitation and relatively low humidity of the northern region reduce Si leaching, suppressing the formation of amorphous materials and transforming active $\mathrm{Al}$ and $\mathrm{Fe}$ into crystalline minerals [16]. In previous research, layered silicates were reported to be predominant clay minerals, with low fractions of amorphous materials, in the soils of the Songag and Donghong series from the northern region of Jeju Island [19] and the Dangsanbong soil from the southern coastal area [20]. In addition, Song and Yoo [17] reported that allophane is rarely found in the soils of the northern region and western coastal area of Jeju Island characterized by relatively low precipitation and that soils at higher elevations with higher precipitation rates have higher allophane contents than soils at lower elevation. Parfitt et al. [38] noted that soils in the regions with 2,600 mm MAP in New Zealand had high Si leaching rates, leading to low Si concentrations in the soil solution where Si develops into 
Pyeongdae Bw2 horizon
Jeju

Bt2 horizon

H
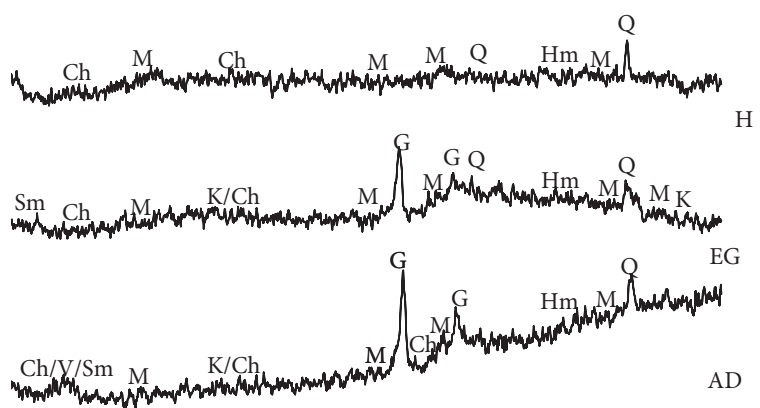

$$
\begin{aligned}
& \text { Namwon } \\
& \text { AB horizon }
\end{aligned}
$$

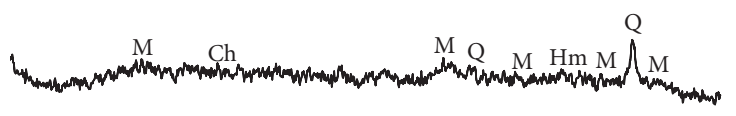

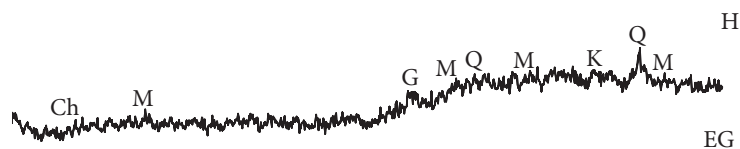

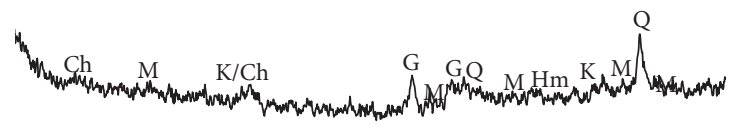

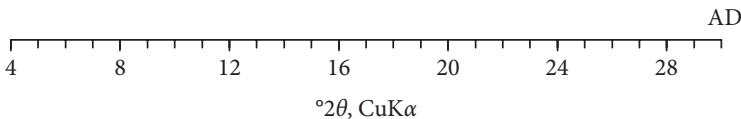

(a)
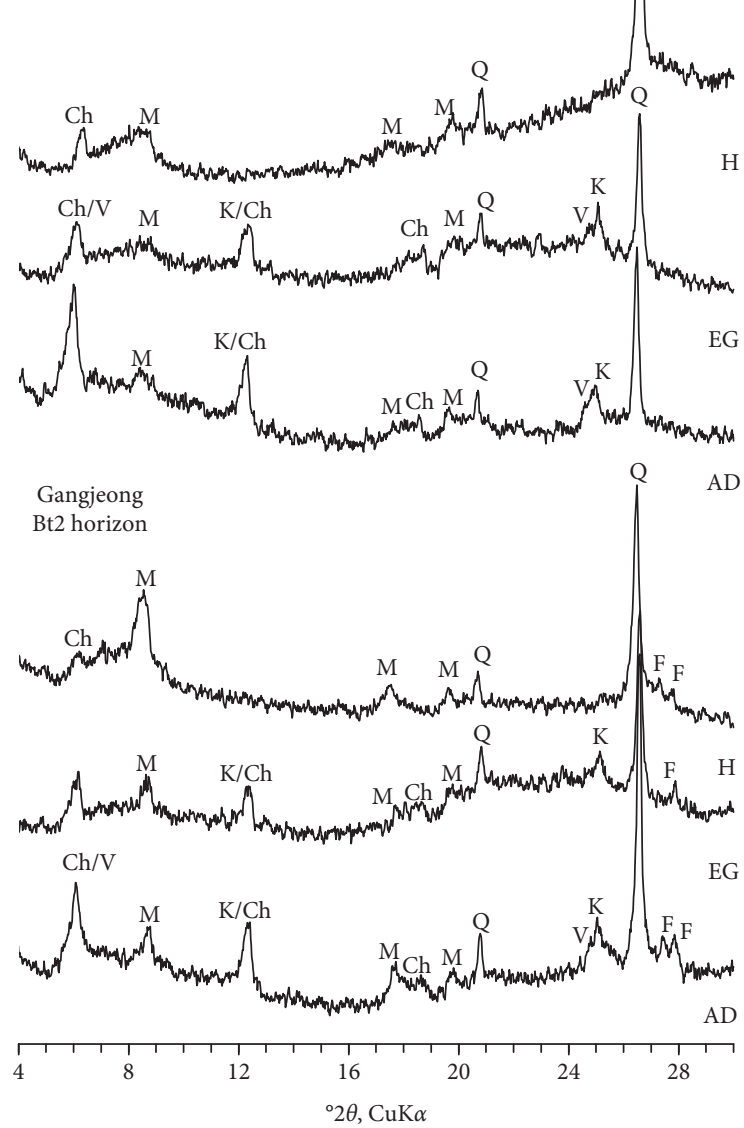

(b)

FIGURE 2: X-ray diffraction patterns of the clay fraction of selected horizons. AD: air-dried; EG: ethylene glycolated; $\mathrm{H}$ : heated at $550^{\circ} \mathrm{C}$; Q: quartz; Ch: chlorite; M: mica/illite; Sm: smectite; K: kaolinite; V: vermiculite; G: gibbsite; F: feldspar; Hm: hematite.
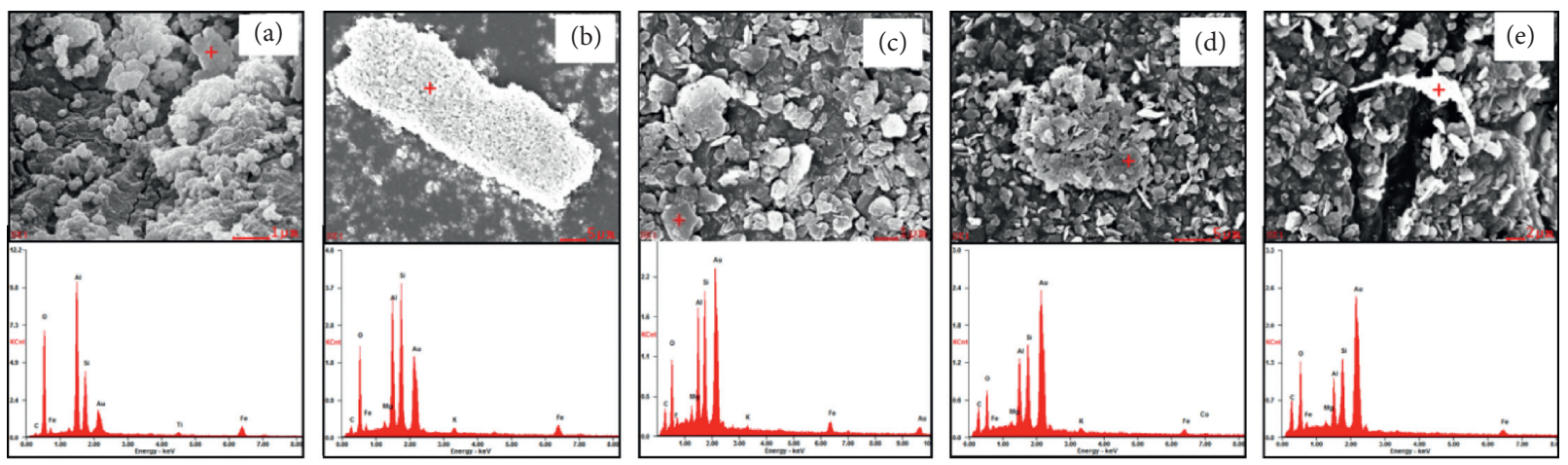

FIGURE 3: SEM/EDS of selected horizons of the profiles less than $2 \mu \mathrm{m}$ in particle size. (a) Allophane in Pyeongdae Bw2 horizon; (b) illite; (c) chlorite in Jeju Bt2 horizon; (d) kaolinite and (e) vermiculite in Gangjeong Bt2 horizon.

allophane $(\mathrm{Al} / \mathrm{Si}=2 / 1)$ via monomeric silicate. They also reported that halloysite $(\mathrm{Al} / \mathrm{Si}=1: 1)$ is formed via polymeric silicate in the regions with $1,200 \mathrm{~mm}$ MAP, where Si concentrations in the soil solution are high because of low $\mathrm{Si}$ leaching rates.
3.3. Mobilities of Si and Al in the Soil Profiles. Figure 4 shows the losses/gains of $\mathrm{Si}$ and $\mathrm{Al}$ in each soil horizon in comparison with the concentration of these elements in bedrocks. Using these measures, we studied the mobility of $\mathrm{Si}$ and $\mathrm{Al}$ in the soils from the two investigated regions. In the 


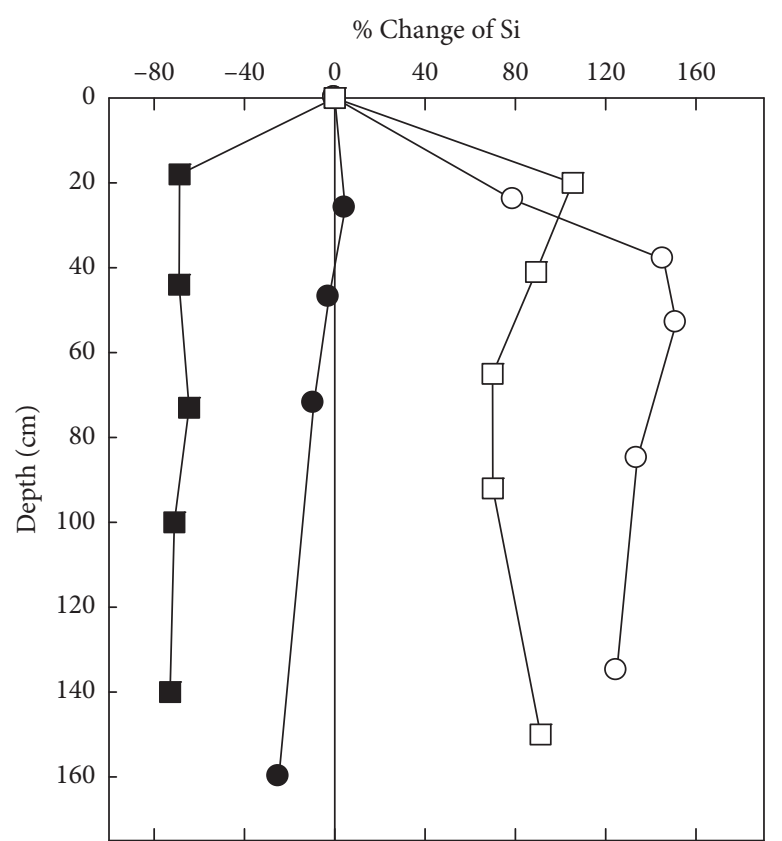

(a)

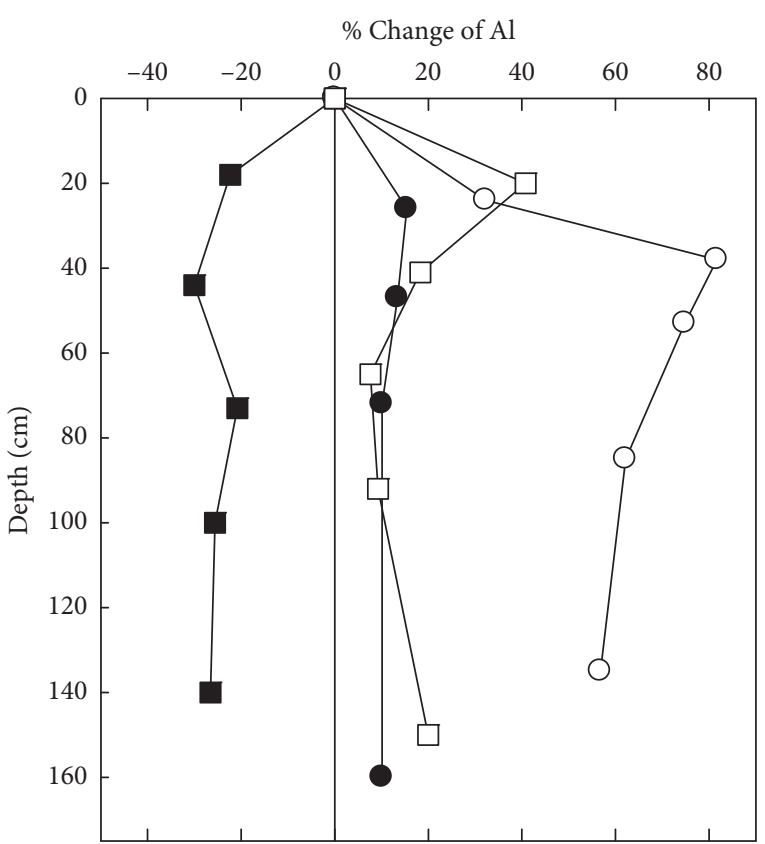

(b)

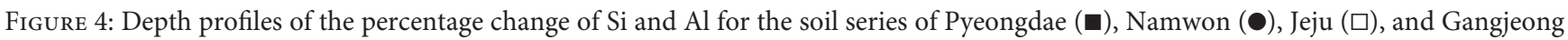
(O) calculated using $\mathrm{Zr}$ as the immobile element.

Jeju and Gangjeong series comprising non-Andisols, whole profile mobility of $\mathrm{Si}$ was highly enriched by $80-150 \%$ compared with those in the bedrock, whereas Si was lost $70 \%$ in all soil horizons of the Pyeongdae series and 25\% in the Bw horizon of the Namwon series compared with those in the bedrock comprising Andisols. Only in the soils from the Pyeongdae series, $\mathrm{Al}$ underwent losses of $20-30 \%$ relative to the bedrock, and $\mathrm{Al}$ gains were recorded in all other investigated soil series.

Figure 5 shows the MAP of each region where the soil samples were collected and the depth-weighted average of the percent change of $\mathrm{Si}$ and $\mathrm{Al}$ down to a depth of $1 \mathrm{~m}$. In the Jeju and Gangjeong series with low MAP $(<1,800 \mathrm{~mm})$, Si was increased by $80 \%$ and $125 \%$, respectively, as did $\mathrm{Al}$ (16\% and $60 \%$, respectively), compared with those in the soils of Pyeongdae and Namwon series with high MAP $(>2,500 \mathrm{~mm})$. In the soils of the Pyeongdae series from the eastern region with high $\mathrm{MAP}, \mathrm{Si}$ and $\mathrm{Al}$ underwent losses of $70 \%$ and $25 \%$, respectively. Compared with the soils from the Pyeongdae series, Si and Al incurred 10\% loss and 10\% gain, respectively, in the soils of the Namwon series with lowMAP.

Given that the Jeju and Gangjeong series developed into non-Andisols from parent materials derived from basaltic pyroclastic materials, highly soluble elements such as $\mathrm{Ca}$ and $\mathrm{Na}$ were leached in large quantities during pedogenesis. However, $\mathrm{Si}$ and $\mathrm{Al}$ fractions were high because most Si and $\mathrm{Al}$ remained in the soils as the main constituents of quartz or components of silicate clay minerals such as kaolinite, illite, and chlorite. In a previous study on the mineralogical evolution of non-Andisol soils in Dangsanbong in the western coastal area of Jeju Island, Ha et al. [20] reported that low precipitation (1,280 mm MAP) reduced Si leaching, which suppressed the formation of amorphous materials, thus leaving layered silicates, such as smectite, kaolinite, chlorite, and vermiculite, as the main constituent minerals.

Quartz, which was not detected in basaltic bedrocks, was observed in all soil samples (Table 4), and Si concentrations varied according to the difference in the quartz contents in the investigated soil profiles. Shin and Tavernier [19] and Ahn and Chon [35] reported that the quartz found in the soils of Jeju Island can be traced back to the acidic volcanic eruptions. In the present study, quartz concentrations were two times higher in non-Andisols (Jeju and Gangjeong series) and developed in relatively dry regions with high evaporation rates than those in Andisols (Pyeongdae and Namwon series), presumably because the crystallization of the vitric components of volcanic acid soils is faster in dry regions than in wet ones. Si concentrations in soil solutions ranged from 15 to $20 \mathrm{mg} \cdot \mathrm{L}^{-1}$, and Si supersaturation resulted in the formation of polymers at $60 \mathrm{mg} \cdot \mathrm{L}^{-1}$ or higher, beyond the solubility of amorphous Si [39]. Quartz, which is one of the most weathering-resistant minerals, is synthesized from soluble Si through the processes of aging of silica hydrogel, pedogenic transformation of opal to quartz in duripans and in silica cemented soils, and diagenetic transformation of opal-A to opal-CT in sediments $[39,40,41]$. The Yongdang series developed in the western and northern regions of Jeju Island contain fragipan in the subsoil horizons $[15,42]$, and the formation of fragipan is associated with $\mathrm{Si}$ accumulation [39]. In contrast, regions where Andisols are distributed have higher precipitation rates, more intense Si leaching, and lower Si concentration in the soil solution than those in the non-Andisol regions, resulting in increased formation of 

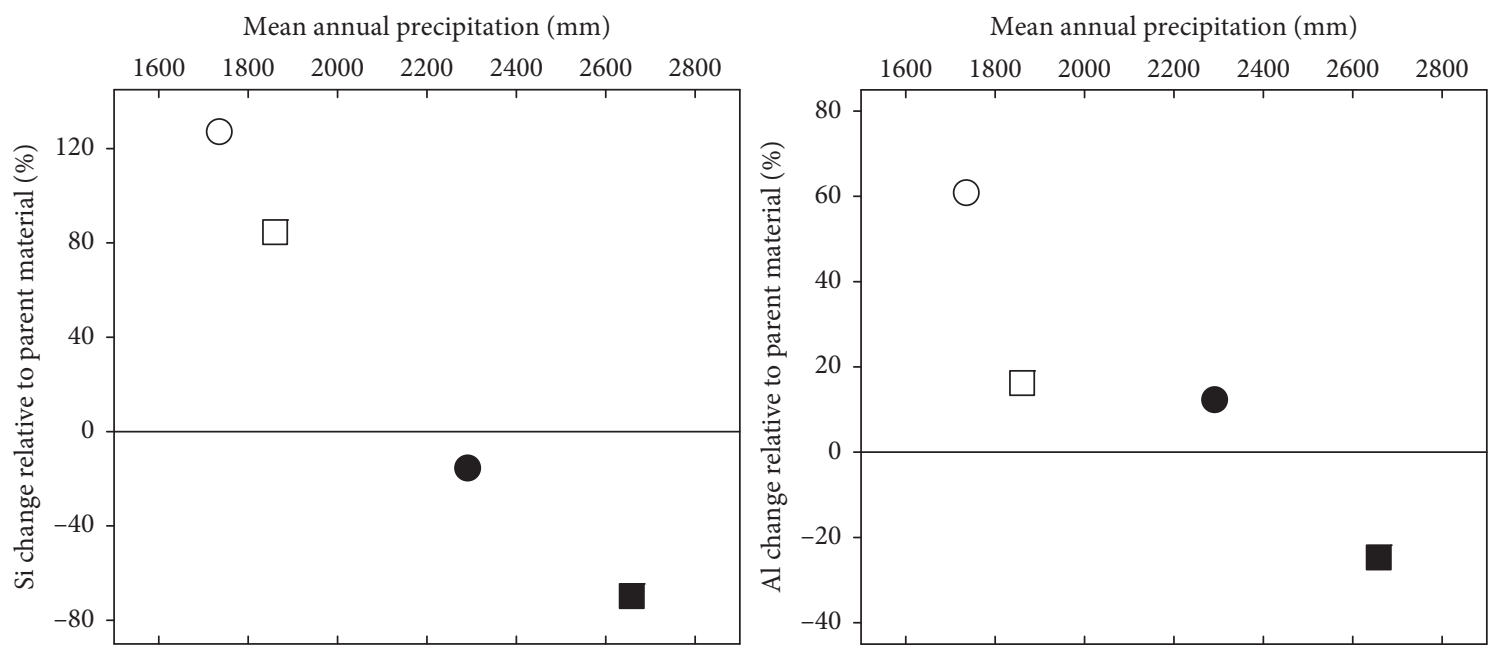

Figure 5: The percentage change of $\mathrm{Si}$ and $\mathrm{Al}$ in the soil series of Pyeongdae ($(\boldsymbol{\square})$, Namwon $(\bullet)$, Jeju ( $\square$ ), and Gangjeong $(\bigcirc)$ from Jeju Island rainfall gradient as a function of mean annual rainfall. Each point was generated by depth integration to $1 \mathrm{~m}$ of soil horizon data.

amorphous materials and lower quartz concentrations. Moreover, although $\mathrm{Si}$ in quartz is weathering-resistant with a solubility of 3-7 mg Si L-1 [41], in the soils of the eastern region, preexisting quartz dissolves as a result of high precipitation, leading to Si leaching.

In the Pyeongdae and Namwon series characterized by Andisols, the ratio between allophane and Al-humus complexes present in soil profiles determines the $\mathrm{Si}$ and $\mathrm{Al}$ mobility. $\mathrm{Al}$ is well-reserved in the Namwon series, given the presence of Al-humus complexes down to the depth of $70 \mathrm{~cm}$, which lowers the fluidity of $\mathrm{Al}$, resulting in its continuous accumulation. In the Pyeongdae series, however, Al-humus complexes are formed only in the A horizon $(18 \mathrm{~cm})$, with allophane present in all horizons of the profile, indicating that formation of Al-humus complexes decreased the mobilization of Al. During pedogenesis, Si losses induce the formation of Al-humus complexes in the volcanic ash soil surface horizon, and the dissolved $\mathrm{Si}$ is mobilized downwards, leading to the formation of allophane with lower Si concentrations in the subsoil horizon, which in turn causes continuous leaching of dissolved Si. The subsoil horizons of the soils from the Pyeongdae and Namwon series had high allophane and gibbsite content (Table 4). Gibbsite is easily formed in Andisols under the perudic soil moisture regime (SMR) in the presence of Si leached out from allophane $[9,43]$. These results indicated that a higher amount of Si is leached in Andisols than in non-Andisols, and it is subsequently mobilized downwards in the soil profile, thus affecting the $\mathrm{Si}$ concentration in groundwater.

Figure 6 illustrates the pedogenesis and development of Andisols and non-Andisols from basaltic pyroclastic materials based on the results of this study on Jeju Island soils and the results obtained in previous studies. The rapid weathering rates of pyroclastic materials are associated with high solubilities of $\mathrm{Si}, \mathrm{Al}$, and $\mathrm{Fe}$ [10]. In the presence of abundant organic matter sources and in humid-temperate climates, $\mathrm{Al}$ and $\mathrm{Fe}$ are bound to organic matter and form $\mathrm{Al}$ $(\mathrm{Fe})$ humus complexes. Because of the high resistance of Alhumus complexes to microbial degradation, large amounts of organic matter are accumulated in these soils, resulting in the decrease of $\mathrm{pH}$ below 4.9 as a consequence of the dissociation of organic acids as well as the increased activity of organic acids that favors the formation of Al-humus complexes $[9,10,44]$. Under these conditions, dissolved $\mathrm{Si}$ is mobilized downwards to the subsoil horizon, and opaline silica is formed because of the increase in Si concentration in soil solution under semi-dry climate conditions compared with that under wetter conditions $[9,10]$. However, if the supply of organic matter decreases or the $\mathrm{pH}$ rises above 5.0, the formation of Al-humus complexes slows down even in the surface horizon, allophane or imogolite are formed by the co-precipitation of $\mathrm{Al}$ and $\mathrm{Si}$, and $\mathrm{Fe}$ precipitates as ferrihydrite $[9,17]$.

With the increasing depth of the soil profile, the supply of organic matter decreases, thus hampering the formation of Al-humus complexes and decreasing the concentrations of organic acids, and the $\mathrm{pH}$ increases closer to or over 5 . Because of this $\mathrm{pH}$ change, the concentration of $\mathrm{Al}$ in the soil solution increases, and $\mathrm{Al}$ is polymerized and exists in the form of oxide or hydroxide $[9,44]$. Under high precipitation conditions, the concentration of dissolved $\mathrm{Si}$ in the soil solution is lower than that under low precipitation conditions and exists as monomeric $\mathrm{Si}$ which is bound to $\mathrm{Al}$ to form allophane $[9,44]$. Allophane induces the formation of Al-rich allophanes $(\mathrm{Al} / \mathrm{Si}=2 / 1)$ rather than Si-rich allophanes $(\mathrm{Al} / \mathrm{Si}=1 / 1)$ [11]. Over time, dehydration and structural rearrangement of allophane and imogolite occur, resulting in the formation of halloysite, unless severe desilication takes place, or even the formation of gibbsite in the event of extremely severe desilication $[9,43,45]$. In ustic or xeric SMR, seasonal dryness tends to accelerate the formation of crystalline clay minerals, whereas short-rangeorder mineral formation is likely to persist in perudic SMR $[10,45]$. As Al-humus complexes and allophane are formed during pedogenic processes, dissolved Si exists in the soil in a form which facilitates mobilization or is mobilized downwards by heavy precipitation. For this reason, we can conclude that the $\mathrm{Si}$ concentration in the groundwater of 


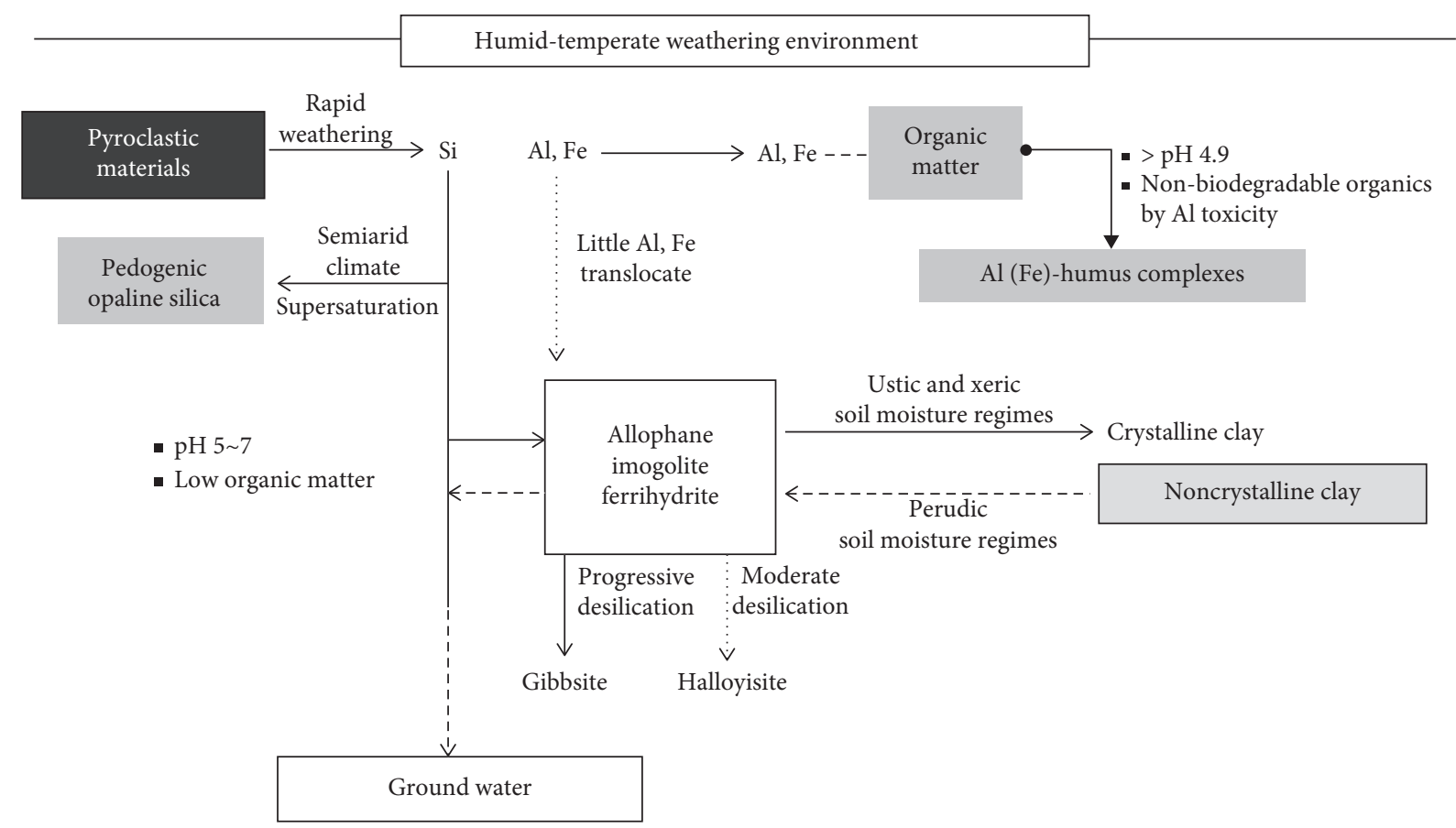

FIGURE 6: Schematic illustration of the possible formation and transformation of clay minerals and humus complexes in volcanic ash soils derived from pyroclastic materials in a humid-temperate climate on Jeju Island.

Jeju Island is maintained high by $\mathrm{Si}$ leaching from the process of pedogenesis of volcanic ash soils.

\section{Conclusions}

In the present study, we investigated the changes in the dynamics of minerals in the soils developed into Andisols (Pyeongdae and Namwon series) in the eastern region and those developed into non-Andisols (Jeju and Gangjeong series) in the northern region of Jeju Island. Si and $\mathrm{Al}$ mobility pattern variations were also investigated according to the chemical composition of the soil profiles. As a result, it was determined that plagioclase, K-feldspar, pyroxene, and magnetite are contained in the bedrocks as the main constituent minerals in all weathered soils. Illite and chlorite were found in most clay minerals, while kaolinite, smectite, and vermiculite were present in some soils in small quantities. In the non-Andisols of the northern region, quartz content ranged between 45 and 55\%, which was twice as high as that in Andisols, and Allophane was not found in non-Andisols, which aligned with limited $\mathrm{Si}$ leaching. Al-humus complexes, allophane, and gibbsite were formed in Andisols, and gibbsite concentrations corresponded with high allophane concentrations. Andisols and non-Andisols were both developed from basaltic pyroclastic materials, but in non-Andisols with 1,800 mm MAP, quartz and layer silicate clay minerals were formed, with little $\mathrm{Si}$ and Al leaching observed. In Andisols with >2,000 mm MAP, Si leaching increased in the soils that formed large amounts of allophane and gibbsite. $\mathrm{Al}$ was preserved by forming Al-humus complexes or forming parts of silicate clay minerals. These results indicated that the high Si concentration in the groundwater in volcanic ash soils of
Jeju Island can primarily be ascribed to the pedogenesis of Andisols. The amount of precipitation and the presence of materials such as allophane significantly impacted Si concentration and mobility in Andisols. Because Andisols are widely distributed across Jeju Island and allophane can be formed continuously in humid-temperate weather conditions, this will greatly contribute to the increase in Si concentrations in the groundwater of Jeju Island.

\section{Data Availability}

The research data used to support the findings of this study are included within the article.

\section{Conflicts of Interest}

The authors declare that they have no conflicts of interest.

\section{Acknowledgments}

The authors gratefully acknowledge Dr. Hae-Nam Hyun for his financial support through Jeju National University Research Fund in 2014 and 2017 and critical discussions and Dr. Hyomin Lee for his technical assistance.

\section{Supplementary Materials}

Table S1: the content of elements on the fine earth fractions ( $2 \mathrm{~mm})$ of soil samples and basaltic bedrocks. (Supplementary Materials) 


\section{References}

[1] W. P. Park, K. C. Song, B. J. Koo, and H. N. Hyun, "Distribution of available silicon of volcanic ash soils in Jeju Island," Applied and Environmental Soil Science, vol. 2019, Article ID 2729694, 2019.

[2] Y. C. Song, S. S. Oh, I. H. Hyun, T. G. Oh, and S. M. Kim, "Distribution of vital mineral groundwaters in Jeju," Report of Jeju Special Self-Governing Provincial Environmental Resources Institute, vol. 2, pp. 254-267, 2009, in Korean with English abstract.

[3] K. G. Kang, "Studies on the hydrogeochemical processes and characteristics of groundwater in the Pyoseon Watershed, Jeju Province, Korea," Ph.D. thesis, Jeju National University, Jeju, South Korea, 2010, in Korean with English abstract.

[4] S. Hashimoto, M. Fujita, K. Furukawa, and J.-I. Minami, Indices of drinking water concerned with taste and health Journal of Fermentation Technology, vol. 65, no. 2, pp. 185192, 1987.

[5] J. A. Edwardson, P. B. Moore, I. N. Ferrier et al., "Effect of silicon on gastrointestinal absorption of aluminum," The Lancet, vol. 342, no. 8865, pp. 211-212, 1993.

[6] M. R. Calomme and D. A. Vanden Berghe, "Supplementation of calves with stabilized orthosilicic acid," Biological Trace Element Research, vol. 56, no. 2, pp. 153-165, 1997.

[7] S. Gillette-Guyonnet, S. Andrieu, and B. Vellas, "The potential influence of silica present in drinking water on Alzheimer's disease and associated disorders," The Journal of Nutrition, Health \& Aging, vol. 11, no. 2, pp. 119-124, 2007.

[8] A. Mair, B. Hagedorn, S. Tillery et al., "Temporal and spatial variability of groundwater recharge on Jeju Island, Korea," Journal of Hydrology, vol. 501, pp. 213-226, 2013.

[9] S. Shoji, M. Nanzyo, and R. A. Dahlgren, "Volcanic ash soils: genesis, properties and utilization," in Developments in Soil Science, vol. 21 Elsevier, Amsterdam, The Netherlands, 1993.

[10] F. C. Ugoline and R. A. Dahlgren, "Soil development in volcanic ash," Global Environmental Research, vol. 6, no. 2, pp. 69-81, 2002.

[11] R. L. Parfitt and J. M. Kimble, "Conditions for formation of allophane in soils," Soil Science Society of America Journal, vol. 53, no. 3, pp. 971-977, 1989.

[12] F. Zehetner, W. P. Miller, and L. T. West, "Pedogenesis of volcanic ash soils in Andean Ecuador," Soil Science Society of America Journal, vol. 67, no. 6, pp. 1797-1809, 2003.

[13] C. C. Tsai, Z. S. Chen, C. I. Kao et al., "Pedogenic development of volcanic ash soils along a climosequence in Northern Taiwan," Geoderma, vol. 156, no. 1-2, pp. 48-59, 2010.

[14] S. Opfergelt, R. B. Georg, B. Delvaux et al., "Silicon isotopes and the tracing of desilication in volcanic soil weathering sequences, Guadeloupe," Chemical Geology, vol. 326-327, pp. 113-122, 2012.

[15] National Academy of Agricultural Science, Taxonomical Classification of Korean Soils, Rural Development Administration, Suwon, South Korea, 2014.

[16] K. C. Song, B. G. Hyun, K. H. Moon et al., "Taxonomical classification and genesis of Jeju series in Jeju Island," Korean Journal of Soil Science and Fertilizer, vol. 43, no. 2, pp. 230236, 2010, in Korean with English abstract.

[17] K. C. Song and S. H. Yoo, "Andic properties of major soils in Cheju Island. III. Conditions for formation of allophane," Korean Journal of Soil Science and Fertilizer, vol. 27, no. 3, pp. 149-157, 1994, in Korean with English abstract.

[18] J. S. Shin and G. Stoops, "Composition and genesis of volcanic ash soils in Jeju Island I. physico-chemical and macro- micromorphological properties," Journal of the Mineralogical Society of Korea, vol. 1, no. 1, pp. 32-39, 1988.

[19] J. S. Shin and R. Tavernier, "Composition and genesis of volcanic ash soils in Jeju Island, II. Mineralogy of sand, silt and clay fractions," Journal of the Mineralogical Society of Korea, vol. 1, no. 1, pp. 40-47, 1988.

[20] D. H. Ha, J. H. Yoo, H. S. Moon, G. H. Lee, and Y. G. Song, "Mineralogical evolution of non-Andic Soils, Jeju Island," Economic and Environmental Geology, vol. 35, no. 6, pp. 491-508, 2002.

[21] S. S. Zhang, Y. H. Kim, K. C. Song, and S. K. Kim, "Mineralogical characteristics of the Noro and Miag series soils developed on the cinder cones in Jeju Island," Korean Journal of Soil Science and Fertilizer, vol. 35, no. 3, pp. 145-152, 2002, in Korean with English abstract.

[22] A. Nieuwenhuyse and N. van Breemen, "Quantitative aspects of weathering and neoformation in selected Costa Rican Volcanic Soils," Soil Science Society of America Journal, vol. 61, no. 5, pp. 1450-1458, 1997.

[23] A. C. Kurtz, L. A. Derry, O. A. Chadwick, and M. J. Alfano, "Refractory element mobility in volcanic soils," Geology, vol. 28, no. 8, pp. 683-686, 2000.

[24] O. A. Chadwick, R. T. Gavenda, E. F. Kelly et al., "The impact of climate on the biogeochemical functioning of volcanic soils," Chemical Geology, vol. 202, no. 3-4, pp. 195-223, 2003.

[25] M. G. Di Figlia, A. Bellanca, R. Neri, and A. Stefansson, "Chemical weathering of volcanic rocks at the island of Pantelleria, Italy: information from soil profile and soil solution investigations," Chemical Geology, vol. 246, no. 1-2, pp. 1-18, 2007.

[26] Korea Meteorological Administration, Climatological Normals of Korea, Korea Meteorological Administration, Seoul, South Korea, 2011.

[27] Korea Institute of Geoscience and Mineral Resources (KIGAM), Assessment of Sustainable Groundwater Availability and Development of High Value Added Groundwater in Jeju Island, Korea Institute of Geoscience and Mineral Resources, Daejeon, South Korea, 2011.

[28] R. Burt, Soil Survey Laboratory Methods Manual.Soil Survey Investigations Report No. 42, Version 4.0, Natural Resources Conservation Service, US Department of Agriculture, Washington, DC, USA, 2004.

[29] C. Mizota and L. P. van Reeuwijk, Clay Mineralogy and Chemistry of Soils Formed in Volcanic Material in Diverse Climatic Regions in Soil Monograph2, International Soil Reference and Information Center, Wageningen, Netherlands, 1989.

[30] C. W. Childs, N. Matsue, and N. Yoshinaga, "Ferrihydrite in volcanic ash soils of Japan," Soil Science and Plant Nutrition, vol. 37, no. 2, pp. 299-311, 1991.

[31] USDA, Keys to Soil Taxonomy, Soil Survey Staff,Natural Resources Conservation Service, US Department of Agriculture, Washington, DC, USA, 12th edition, 2014.

[32] J. L. Ma, G. J. Wei, Y. G. Xu, W. G. Long, and W. D. Sun, "Mobilization and re-distribution of major and trace elements during extreme weathering of basalt in Hainan Island, South China," Geochimica et Cosmochimica Acta, vol. 71, no. 13, pp. 3223-3237, 2007.

[33] K. Jiang, H. W. Qi, and R. Z. Hu, "Element mobilization and redistribution under extreme tropical weathering of basalts from the Hainan Island, South China," Journal of Asian Earth Sciences, vol. 158, pp. 80-102, 2018.

[34] J. B. Park and S. T. Kwon, "Geochemical evolution of the Cheju volcanic Island: petrography and major element 
chemistry for stratigraphically-controlled lavas from the northern part of Cheju Island," Journal of Geological Society of Korea, vol. 29, no. 1, pp. 39-60, 1993, in Korean with English abstract.

[35] J. S. Ahn and C. M. Chon, "Geochemical distributions of heavy metals and $\mathrm{Cr}$ behavior in natural and cultivated soils of Volcanic Jeju Island, Korea," Geosystem Engineering, vol. 13, no. 1, pp. 9-20, 2010.

[36] S. Shoji, M. Nanjyo, R. A. Dahlgren, and P. Quantin, "Evaluation and proposed revisions of criteria for Andosols in the world reference base for soil resources," Soil Science, vol. 161, no. 9, pp. 604-615, 1996.

[37] A. Imaya, Y. Inagaki, N. Tanaka, and S. Ohta, "Free oxides and short-range ordered mineral properties of brown forest soils developed from different parent materials in the submontane zone of the Kanto and Chubu districts, Japan," Soil Science and Plant Nutrition, vol. 53, no. 5, pp. 621-633, 2007.

[38] R. L. Parfitt, M. Russell, and G. E. Orbell, "Weathering sequence of soils from volcanic ash involving allophane and Halloysite, New Zealand," Geoderma, vol. 29, no. 1, pp. 41-57, 1983.

[39] M. Sommer, D. Kaczorek, Y. Kuzyakov, and J. Breuer, "Silicon pools and fluxes in soils and landscapes-a review," Journal of Plant Nutrition and Soil Science, vol. 169, no. 3, pp. 310-329, 2006.

[40] J.-T. Cornelis, B. Delvaux, R. B. Georg, Y. Lucas, J. Ranger, and S. Opfergelt, "Tracing the origin of dissolved silicon transferred from various soil-plant systems towards rivers: a review," Biogeosciences, vol. 8, no. 1, pp. 89-112, 2011.

[41] L. R. Drees, L. P. Wilding, N. E. Smeck, and A. L. Sankayi, "Silica in soils: quartz and disordered silica polymorphs," in Minerals in Soil Environments, SSSA Book Series No.1, J. B. Dixon and S. B. Weed, Eds., pp. 913-974, Madison, WI, USA, 1989.

[42] K. C. Song, B. G. Hyun, K. H. Moon, S. J. Jeon, and H. C. Lim, "Taxonomical classification of yongdang series," Korean Journal of Soil Science and Fertilizer, vol. 42, no. 5, pp. 393398, 2009, in Korean.

[43] S. Ndayiragije and B. Delvaux, "Coexistence of allophane, gibbsite, kaolinite and hydroxy-Al-interlayered 2: 1 clay minerals in a perudic Andosol," Geoderma, vol. 117, no. 3-4, pp. 203-214, 2003.

[44] F. C. Ugoline and R. A. Dahlgren, "Weathering environments and occurrence of imogolite/allophane in selected Andisols and Spodosols," Soil Science Society of America Journal, vol. 55, no. 4, pp. 1166-1171, 1991.

[45] S. W. Buol, R. J. Southard, R. C. Graham, and R. A. McDaniel, "Andisols: soils with andic soil properties," in Soil Genesis and Classification, Iowa State Press, Iowa, IA, USA, 5th edition, 1997. 